\title{
Are Microglial Cells the Regulators of Lymphocyte Responses in the CNS?
}

\author{
Beatriz Almolda*, Berta González and Bernardo Castellano \\ Department of Cell Biology, Physiology and Immunology, Facultat de Medicina, Institute of Neurosciences, Universitat \\ Autònoma de Barcelona, Bellaterra, Spain
}

The infiltration of immune cells in the central nervous system is a common hallmark in different neuroinflammatory conditions. Accumulating evidence indicates that resident glial cells can establish a cross-talk with infiltrated immune cells, including T-cells, regulating their recruitment, activation and function within the CNS. Although the healthy CNS has been thought to be devoid of professional dendritic cells (DCs), numerous studies have reported the presence of a population of DCs in specific locations such as the meninges, choroid plexuses and the perivascular space. Moreover, the infiltration of DC precursors during neuroinflammatory situations has been proposed, suggesting a putative role of these cells in the regulation of lymphocyte activity within the CNS. On the other hand, under specific circumstances, microglial cells are able to acquire a phenotype of DC expressing a wide range of molecules that equip these cells with all the necessary machinery for communication with T-cells. In this review, we summarize the current knowledge on the expression of molecules involved in the cross-talk with T-cells in both microglial cells and DCs and discuss the potential contribution of each of these cell populations on the control of lymphocyte function within the CNS.

OPEN ACCESS

Edited by:

Gilles J. Guillemin,

Macquarie University, Australia

Reviewed by:

Francesca Fallarino,

University of Perugia, Italy

Dean Louis Pountney,

Griffith University, Australia

*Correspondence:

Beatriz Almolda

beatriz.almolda@uab.cat

Received: 13 July 2015 Accepted: 23 October 2015 Published: 16 November 2015

Citation:

Almolda B, González B and Castellano B (2015) Are Microglial Cells the Regulators of Lymphocyte

Responses in the CNS?

Front. Cell. Neurosci. 9:440. doi: 10.3389/fncel.2015.00440
Keywords: antigen presentation, lymphocyte, dendritic cells, co-stimulatory signals, MHCs, B7, purine nucleotides, CD39

\section{INTRODUCTION}

The central nervous system (CNS) has been considered for many years as an organ immunologically isolated from the peripheral immune system, on one hand due to the presence of the blood brain barrier (BBB) and the absence of lymphatic vessels (Perry, 1998) and, on the other hand, by the fact that skin grafts and the direct inoculation of viruses, bacteria or antigens in the nervous parenchyma did not induce an immune response (Medawar, 1948; Barker and Billingham, 1977; Stevenson et al., 1997; Matyszak and Perry, 1998). Nevertheless, in the last decade, an increasing number of studies has demonstrated that the CNS is not only immune-competent, but it also actively interacts with cells of the peripheral immune system (Aloisi et al., 2000; Becher et al., 2000; Steinman, 2004; Almolda et al., 2011b; Gonzalez et al., 2014), which can be recruited to the nervous parenchyma under specific circumstances (Ransohoff et al., 2003; Engelhardt and Ransohoff, 2005; Becher et al., 2006; Engelhardt, 2006, 2008).

With all of these studies in mind, it is easy to think that the isolated view of the CNS has drastically changed toward a more active scenario, in which a situation of active immune tolerance is continuously maintained within the CNS. Different mechanisms have been reported to contribute to this active tolerance, including the constitutive expression of FasL, a receptor involved in the death of infiltrated immune cells (Bechmann et al., 1999; Flugel et al., 2000) and the local production of anti-inflammatory mediators such as indolamine 2,3-dioxygenase, 
in response to the interaction with pro-inflammatory lymphocytes (Kwidzinski et al., 2005). The presence of some populations of cells, such as macrophages and dendritic cells (DCs), located in strategic areas of the CNS such as the meninges and the choroid plexus, may play a key function in the initiation and regulation of immune responses. Nowadays, then, the $\mathrm{CNS}$ is considered as an immune-privileged site, rather than immune-isolated (Ousman and Kubes, 2012; Ransohoff and Engelhardt, 2012).

\section{INFILTRATION OF LYMPHOCYTES IN THE CNS UNDER PATHOLOGICAL SITUATIONS}

The infiltration of lymphocytes within the CNS parenchyma is a common hallmark in many pathological conditions (RezaiZadeh et al., 2009; Anderson et al., 2014) such as VIH (Petito et al., 2003) and West Nile virus infection (Glass et al., 2005); neurodegenerative diseases such as Parkinson's disease (Brochard et al., 2009) and amyotrophic lateral sclerosis (Holmoy, 2008); acute lesions like facial nerve axotomy (Raivich et al., 1998), entorhinal cortex lesion (Babcock et al., 2008), stroke (Schroeter et al., 1994; Gelderblom et al., 2009) and ischemia (Gelderblom et al., 2009) or autoimmune processes such as experimental autoimmune encephalomyelitis (Dittel, 2008; Almolda et al., 2011a). While in some circumstances lymphocyte infiltration has been related to protective functions, as occurs in the facial nerve axotomy paradigm (Serpe et al., 1999), the West Nile virus infection (Glass et al., 2005) and amyotrophic lateral sclerosis (Beers et al., 2008; Chiu et al., 2008), in other circumstances lymphocyte infiltration has been shown to contribute to the exacerbation of the pathology. This is the case of Parkinson's disease (Brochard et al., 2009), VIH virus infection (Petito et al., 2003), stroke (Yilmaz et al., 2006) and some autoimmune diseases (Dittel, 2008).

Due to the fact that T-cells are not able to recognize soluble antigens, they need the help of specialized cells, the socalled antigen presenting cells (APCs), which through antigen presentation mechanisms can capture, process and present pathogen and viral antigens and other strange structures for recognition by T-cells. Depending on the pattern of cytokine secretion, the functions and the molecules that drive their differentiation, different subtypes of T-helper lymphocytes are identified (Reinhardt et al., 2006; Takatori et al., 2008; Sun and Zhang, 2014). Classical classification considers two different subtypes: T-helper 1 (Th1) lymphocytes, which secrete proinflammatory cytokines such as interferon- $\gamma($ IFN- $\gamma$ ) or tumoral necrosis factor- $\alpha$ (TNF- $\alpha$ ) and Th2 lymphocytes, which produce anti-inflammatory cytokines such as interleukin-4 (IL-4) and interleukin-10 (IL-10). Therefore, Th1 accumulation has been usually considered as an inflammatory event, whereas presence of Th2 has been related to the down-regulation of the inflammatory response. However, a growing accumulation of evidence has changed this simple paradigm based on the presence/absence of Th1/Th2, as other subpopulations of Th cells have been discovered, among them, effector T-cells including Th17, Th22,
Th9, T-follicular helper (Tfh) cells with the capacity to secrete different cytokines (Cosmi et al., 2014), but also regulatory T-cells such as T-regulatory (Treg) and Tr1, whose principal function is to maintain the immune system homeostasis and the tolerance to self-antigens (Bluestone and Tang, 2005; Eltzschig et al., 2012; Piccioni et al., 2014). Two different subtypes of Treg are currently identified: the natural Treg (nTreg) and the induced Treg (iTreg) (Horwitz et al., 2008; Curotto de Lafaille and Lafaille, 2009; Piccioni et al., 2014). The nTregs, defined as $\mathrm{CD} 4+\mathrm{CD} 25+$ Foxp3+ cells, are generated in the thymus during the maturation of T-cells by recognition of self-peptides with intermediate affinity, whereas the iTregs are produced in secondary lymphoid organs (spleen and lymph nodes) from naïve CD4+Foxp3- T-cells under both homeostatic conditions and in the presence of inflammation, infection or allergy after stimulation with TGF- $\beta$ (Piccioni et al., 2014). Due to their capacity to suppress immune responses, the participation of Tregs in the evolution of acquired immune responses in the CNS, especially those related to autoimmunity, has generated much attention in the last several years. In this sense a remarkable accumulation of Tregs in cerebral gliomas (Grauer et al., 2007), ischemic stroke (Stubbe et al., 2012) and in some experimental models of encephalomyelitis such as EAE (McGeachy et al., 2005; Kohm et al., 2006; Korn et al., 2007) has been reported.

The discovery of all of these subtypes of lymphocytes with putative new functions in the promotion and modulation of the acquired immune response and their still-unknown interactions with resident $\mathrm{CNS}$ cells, specially microglia, has contributed to becoming aware that the scenario of the neuroimmune response could be even more complicated than previously thought.

\section{ACTIVATED MICROGLIA ARE CONSIDERED THE MAIN APC IN THE CNS}

Microglial cells are considered the sole representative of the immune system within the CNS parenchyma. The precise origin of microglia during development still remains under debate, although emerging evidence reported that yolk-salk primitive precursors are the principal source (Ginhoux et al., 2010, 2013; Schulz et al., 2012). Studies in bone-marrow chimera and parabiotic mice indicated that these yolk-salk precursors invade the CNS parenchyma through the blood vessels around embryonic Day 9 in mice, corresponding to the vascularization process, and contribute substantially to the maintenance of microglial cells in the adult (Ginhoux et al., 2010). However, alternative routes of entry for microglial precursors, including the ventricles and meninges, have been identified (Cuadros and Navascues, 1998; Dalmau et al., 1998, 2003; Navascues et al., 2000). Whether these different routes of entry are linked to different populations of microglial precursors with different functions is an interesting field that is still unsolved.

Microglial cells are equipped with a broad range of receptors in their plasma membrane that allows them to sense subtle changes in the micro-environment (Kettenmann et al., 2011; 
Hanisch, 2013; Kierdorf and Prinz, 2013). Microglial cells play very important roles in healthy, normal CNS, not only during the post-natal period, where they contribute to the elimination of synaptic structures (Pont-Lezica et al., 2011; Tremblay et al., 2011; Harry and Kraft, 2012), but also in the adult, where they are continuously scanning their local micro-environment (Davalos et al., 2005; Nimmerjahn et al., 2005; Kierdorf and Prinz, 2013; Castellano et al., 2015). When the homeostasis of the CNS is perturbed as a result of injury or disease, microglial cells become rapidly activated, acquiring a specific phenotype totally dependent on the environment in which they are activated and the specific stimulus that drives their activation (Kettenmann et al., 2011; Gonzalez et al., 2014; Chen and Trapp, 2015). Activated microglia can rapidly proliferate and increase the expression or de novo express a multitude of different molecules and secrete a plethora of substances such as cytokines, chemokines and trophic factors, all of which make them able to modulate both the innate and the acquired immune responses within the CNS (Ransohoff and Cardona, 2010; Kettenmann et al., 2011; Eggen et al., 2013; Goldmann and Prinz, 2013; Casano and Peri, 2015).

Recognition of the T-cell receptor (TCR) on the surface of T-lymphocytes by the major histocompatibility complexes (MHCs) located on the surface of the APCs, MHC-I in the case of CD8+T-cytotoxic lymphocytes and MHC-II for CD4+Thelper cells, constitutes the first signal of the antigen-presenting mechanism related to the activation of T-cells (Lanzavecchia, 1997; Abbas et al., 2010). Co-stimulation, the second signal involved in this mechanism, is based on the binding of diverse receptors and counter-receptors expressed on the surface of both APC and T-cells (Nurieva et al., 2009) and is essential for a complete antigen presentation, as expression of MHCs in the absence of co-stimulation leads to the apoptosis or anergy of T-cells (Kishimoto and Sprent, 1999). A multitude of costimulatory pairs of molecules, which can be classified into two main families (the B7/CD28 and the TNFR families), have been reported in the immune system, exerting different effects on the activation/deactivation of T-cells (Sharpe, 2009) and driving the final outcome and function of T-cells.

\section{Expression of MHCs in Microglia}

Resident glial cells, principally microglia, can establish a cross-talk with infiltrated T-cells regulating their recruitment, activation and function within the CNS (Gonzalez et al., 2014). Although in healthy CNS microglial cells do not express MHCs (Kreutzberg, 1996; Perry, 1998), it is well known that, when activated in pathological conditions, they showed a wide number of phenotypic changes (Ransohoff and Cardona, 2010; Kettenmann et al., 2011; Prinz et al., 2014), including de novo expression of these molecules (Kreutzberg, 1996; Perry, 1998). Therefore, many authors consider microglial cells as the principal APC within the CNS parenchyma (Aloisi, 2001; Carson, 2002; Raivich and Banati, 2004; Graeber and Streit, 2010). Expression of MHC-II in activated microglia in vivo has been reported after a wide variety of CNS injuries including LPS injection (Xu and Ling, 1995; Ng and Ling, 1997), ischemia and kainic acid injection (Finsen et al., 1993), graft vs. host disease
(Sedgwick et al., 1998), facial nerve axotomy (Streit et al., 1989; Villacampa et al., 2015), entorhinal cortex lesion (Bechmann et al., 2001; Kwidzinski et al., 2003a) and different models of EAE (Almolda et al., 2010).

\section{Expression of Co-stimulatory Molecules in Microglia}

While the expression of MHCs has been extensively reported in activated microglia, only a limited number of studies have addressed the question of whether activated MHC-II+ microglia simultaneously express co-stimulatory molecules (Summarized in Table 1).

\section{The B7/CD28 Family}

The pair of co-stimulatory molecules with the major relevance in the activation of T-cells, and therefore the most extensively studied in the organism, is that formed by receptors B7.1/B7.2 (CD80/CD86) on the surface of APCs and their counterreceptors CD28 and CTLA- 4 on the surface of T-cells. The binding of B7.1 or B7.2 to CD28 induces T-cell proliferation and cytokine secretion, whereas binding of these same receptors to CTLA-4 induces the inhibition of T-cell activity, promoting the down-regulation of the immune response (Sansom, 2000; Sharpe and Freeman, 2002). Specifically in the CNS, de novo expression of B7.1 and/or B7.2 has been reported in microglial cells after entorhinal cortex lesion (Bechmann et al., 2001; Kwidzinski et al., 2003b), peripheral nerve injury (Rutkowski et al., 2004), facial nerve axotomy (Bohatschek et al., 2004), cuprizone-induced demyelination (Remington et al., 2007) and models of autoimmunity such as EAE and Theiler's virus encephalomyelitis (Issazadeh et al., 1998; Juedes and Ruddle, 2001; Mack et al., 2003; Raivich and Banati, 2004; Almolda et al., 2010, 2011b).

Recently, other members of the B7 co-stimulatory molecules family have been described in the immune system, including B7H2 (ICOS-L), B7-H1 (PD-L1), B7-DC (PD-L2), B7H3 (CD276), B7H4, B7S3 and BTNL (Sharpe, 2009; Chen and Flies, 2013). The ICOS-ICOSL pathway has important roles in the finetuning of effector T-cell functions and the control of T-cell tolerance (Nurieva et al., 2009). Although the presence of ICOS+ T-cells has been reported in the CNS of EAE-induced mice (Rottman et al., 2001), to-date, no studies on the expression of its ICOSL ligand on microglia or any other CNS resident cells are available. PD-1 is another receptor gaining attention, due to its crucial role in maintaining peripheral immune tolerance (Nurieva et al., 2009). PD-1 has been shown to be a negative regulator of $\mathrm{T}$-cell responses, expressed at low levels on the surface of T, B and natural killer T-cells, and further induced upon activation. PD-1 has two counter-receptors that are expressed on the surface of APCs, PD-L1 and PD-L2 also called B7H1 and B7DC, respectively (Nurieva et al., 2009). The few reports addressing the expression of this molecule in the CNS demonstrated PD-L1 expression in both activated microglia after middle-cerebral artery occlusion (Ren et al., 2011; Bodhankar et al., 2013), coronavirus infection (Phares et al., 2009), Theiler's murine encephalomyelitis (Duncan and Miller, 2011; Jin et al., 2013) and EAE (Schreiner et al., 2008), 
TABLE 1 | Principal co-stimulatory molecules from the B7/CD28 and TNFR family.

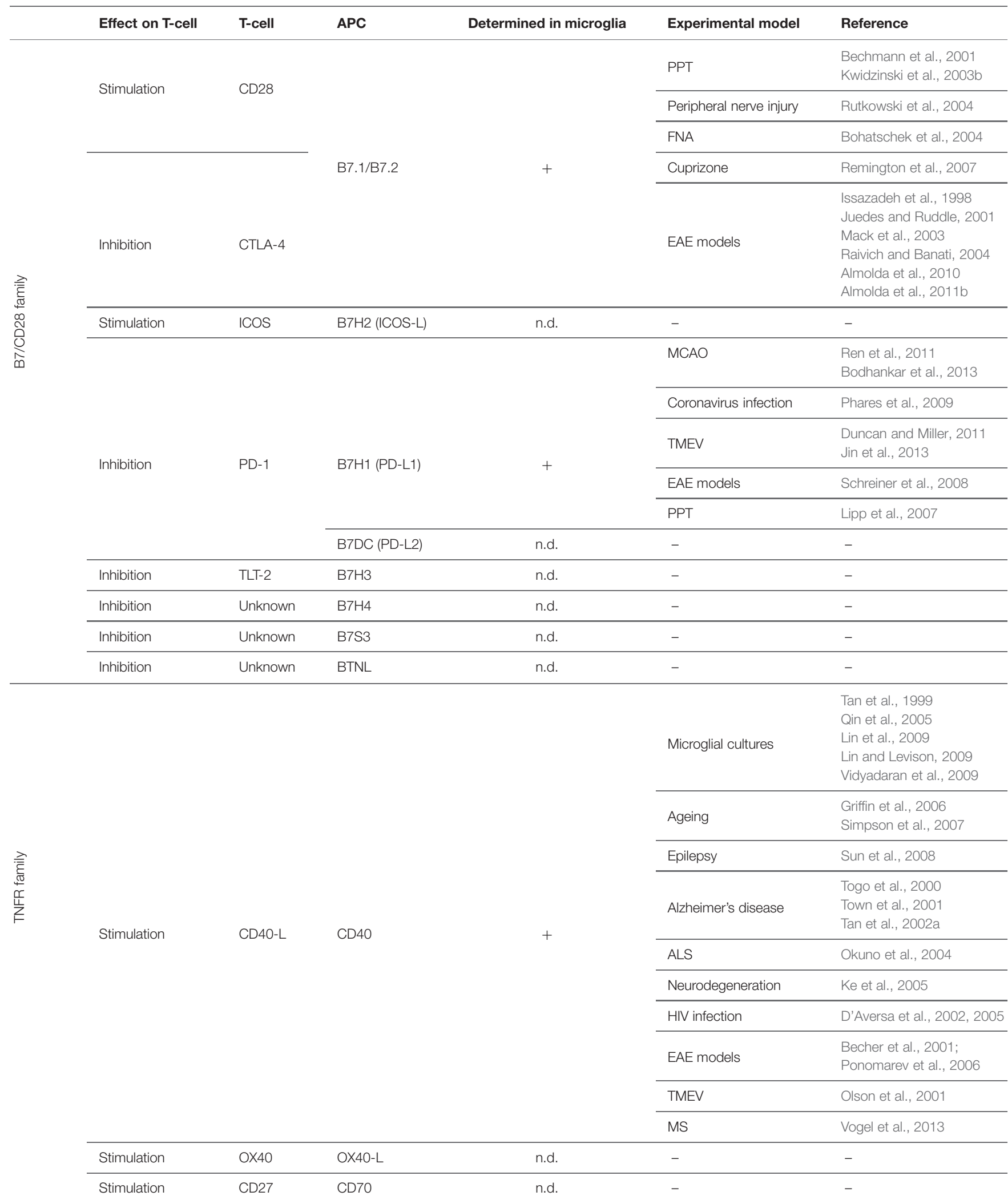

The table summarized the different molecules studied in the context of microglial cells (+). n.d indicates that the expression has not been determined specifically in microglia. PPT, perforant pathway transection; FNA, facial nerve axotomy; EAE, experimental autoimmune encephalomyelitis; MCAO, middle cerebral artery occlusion; TMEV, Theiler's induced encephalitis; ALS, amyotrophic lateral sclerosis; MS, multiple sclerosis. 
and in astrocytes after entorhinal cortex lesion (Lipp et al., 2007). Moreover, the blockade of PD-1 signaling enhances EAE severity (Salama et al., 2003) suggesting an outstanding role in the control of CNS pathologies.

To our knowledge, no studies regarding the expression of $\mathrm{B} 7 \mathrm{H} 3, \mathrm{~B} 7 \mathrm{H} 4, \mathrm{~B} 7 \mathrm{~S} 3$ or BTNL specifically in microglia are, until present, available in the literature.

\section{The TNFR Family}

Additionally, a second family of co-stimulatory receptors, the TNFR family, has been reported in the immune system. Various members, including pairs CD40/CD40L, OX40L/OX40, and CD70/CD27, expressed on APCs and T-cells, respectively, form this family (Watts, 2005; Sharpe, 2009). Among them, CD40 is the only molecule studied in the context of microglial activation (Chen et al., 2006). CD40 expression in activated microglia has been described not only in vitro in many cell-lines activated with IFN- $\gamma$, LPS or $\beta$-amyloid protein (Tan et al., 1999; Qin et al., 2005; Lin and Levison, 2009; Lin et al., 2009; Vidyadaran et al., 2009) but also in vivo during physiological aging (Griffin et al., 2006; Simpson et al., 2007) and under pathological situations such as epilepsy (Sun et al., 2008), Alzheimer's disease (Togo et al., 2000; Town et al., 2001; Tan et al., 2002b), amyotrophic lateral sclerosis (Okuno et al., 2004), neurodegeneration induced by thiamine deficiency (Ke et al., 2005), human HIV (D'Aversa et al., 2002, 2005), different animal models of autoimmunity such as EAE (Becher et al., 2001; Ponomarev et al., 2006) and Theiler's murine encephalomyelitis (Olson et al., 2001) and MS (Vogel et al., 2013). Moreover, inhibition of CD40 in microglia results in the attenuation of $\beta$-amyloid pathology (Tan et al., 2002a) and the reduction of EAE severity (Becher et al., 2001; Ponomarev et al., 2006), pointing toward this molecule as a good candidate for therapeutic interventions in these specific CNS pathologies.

Altogether, these studies indicate that, although so far it seems that microglial cells may be the principal APC within the CNS, in the coming years it will be necessary to inquire about the expression of some other markers related to the antigen-presenting mechanism described in professional DCs and, until now, not explored in the context of microglial activation.

\section{OTHER MOLECULES EXPRESSED BY MICROGLIA THAT CAN BE INVOLVED IN THE COMMUNICATION WITH T-CELLS}

Recent studies indicate that CD39 and CD73, some of the molecules that mediate the immunosuppressive activity of Treg lymphocytes (Deaglio et al., 2007), are also expressed in specific subtypes of APCs and may be involved in the suppressive activity of these cells. Specifically, a subtype of DCs induced by IL27 has been shown to increase expression of CD39 and exert protective functions in EAE (Mascanfroni et al., 2013). CD39 and CD73 (also known as NDPase and 5' nucleotidase, respectively) are enzymes involved in the hydrolysis of extracellular ATP to ADP/AMP and to adenosine. CD39deficiency in DCs has been shown to ameliorate the course of EAE by reducing the number of Th1 and Th17 effector cells (Mascanfroni et al., 2013). The precise mechanism by which CD39 regulates T-cell responses is not clear, although it is proposed to be mediated by a reduction in the ATP levels producing a down-regulation of the inflammasome activity (Eltzschig et al., 2012), a multiprotein-assembled complex involved in the initiation of the immune innate responses (Vanaja et al., 2015).

Expression of both CD39 and CD73 in the membrane of microglial cells has been extensively reported to regulate ATP levels within the CNS, in both healthy situations and after damage (Castellano et al., 2015). Therefore, it is easy to suggest that regulation of the expression of those enzymes in activated microglia take part in modulating the final outcome of infiltrated T-cells.

\section{PRESENCE OF DENDRITIC CELLS IN THE CNS}

Dendritic cells are considered to be the professional APCs in the immune system (Guermonprez et al., 2002). They are derived from hematopoietic stem cells in the bone marrow that gives rise to early precursors called the Common Myeloid Precursor (CMP). CMPs, in turn, originate the formation of two different precursors, the Granulocyte/Monocyte precursors (G/Ms) and the Macrophage/DC precursors (M/DPs). From $\mathrm{M} / \mathrm{DPs}$, the common DC progenitors, the pre-DC precursors and the plasmacytoid DCs are sequentially formed. Pre-DC precursors egress into the blood circulation and populate different organs, including the skin, heart, lung and spleen, becoming conventional DCs (Liu and Nussenzweig, 2010). As both DCs and macrophages derived from the same precursors most of the markers and functions of these two populations are similar.

Although the parenchyma of the normal CNS are devoid of the so-called professional DCs, these cells are abundant in the meninges, the choroid plexus (McMenamin, 1999; McMenamin et al., 2003), the perivascular space and the juxtavascular parenchyma (i.e., the neuropil just beyond the glia limitants) (Prodinger et al., 2010). These locations are considered strategically well-positioned for the communication with bloodcirculating pathogens or T-cells, supporting a role of DCs in the control of the entry gates to the brain and thus in the regulation of immune surveillance in the CNS during homeostasis. With aging, the number of DCs increases markedly in the perivascular space, meninges and choroid plexuses, and has even been found into the brain parenchyma (Stichel and Luebbert, 2007; Kaunzner et al., 2010). The presence of CNS parenchymal DCs has also been reported in different neuroinflammatory situations (McMahon et al., 2006; Colton, 2012; D’Agostino et al., 2012), including infections (Fischer and Reichmann, 2001), traumatic brain injury (Israelsson et al., 2010), ischemia (Kostulas et al., 2002; Reichmann et al., 2002; Felger et al., 2009; Gelderblom et al., 2009), excitotoxicity (Newman et al., 2005) and some diseases such as amyotrophic lateral sclerosis (Henkel et al., 2004), multiple sclerosis (Plumb et al., 2003; Serafini et al., 2006) 
and EAE (Matyszak and Perry, 1996; Serafini et al., 2000; Fischer and Reichmann, 2001; Santambrogio et al., 2001; Santambrogio and Strominger, 2006; Almolda et al., 2010, 2011b).

\section{FUNCTION OF DCS IN THE CNS}

Numerous works (McMahon et al., 2006; Colton, 2012; D'Agostino et al., 2012) emphasize the possible relevance of DCs in the CNS immunosurveillance as well as the function they can play in neuroinflammatory situations. However, the specific contribution of those cells is still not wellunderstood.

The actual knowledge regarding the function of DCs in the brain come from studies using the inoculation of different types of DCs into the CNS under different circumstances. Thus, it has been shown that subcutaneous administration of bone marrow DCs before EAE-induction prevents EAE development in rats (Huang et al., 2000). Other studies reported that intraparenchymal inoculation of tolerogenic DCs, induced by TNF- $\alpha$ treatment, prevents or delays EAE onset, whereas immunogenic DCs administration increases the severity of this disease (Zozulya et al., 2009).

All together, these studies have demonstrated the potential of DCs to serve as potent vehicles to induce tolerance and open a door to new therapeutic strategies to modulate CNS disease. A question not yet addressed in this kind of studies is how these DCs interact with both glial cells and bloodborne infiltrated cells. Research in this field in the coming years is vital to understand the molecular and cellular mechanisms involved in the regulation of immune responses in the CNS.

\section{ARE CNS PARENCHYMAL DCS AUTHENTIC DCS OR ARE THEY A SUBTYPE OF ACTIVATED MICROGLIA?}

In addition to the poor knowledge on the role of DCs in the immune responses within the CNS, one of the issues that generate more controversy is the origin of parenchymal DCs observed in a wide range of neuroinflammatory situations

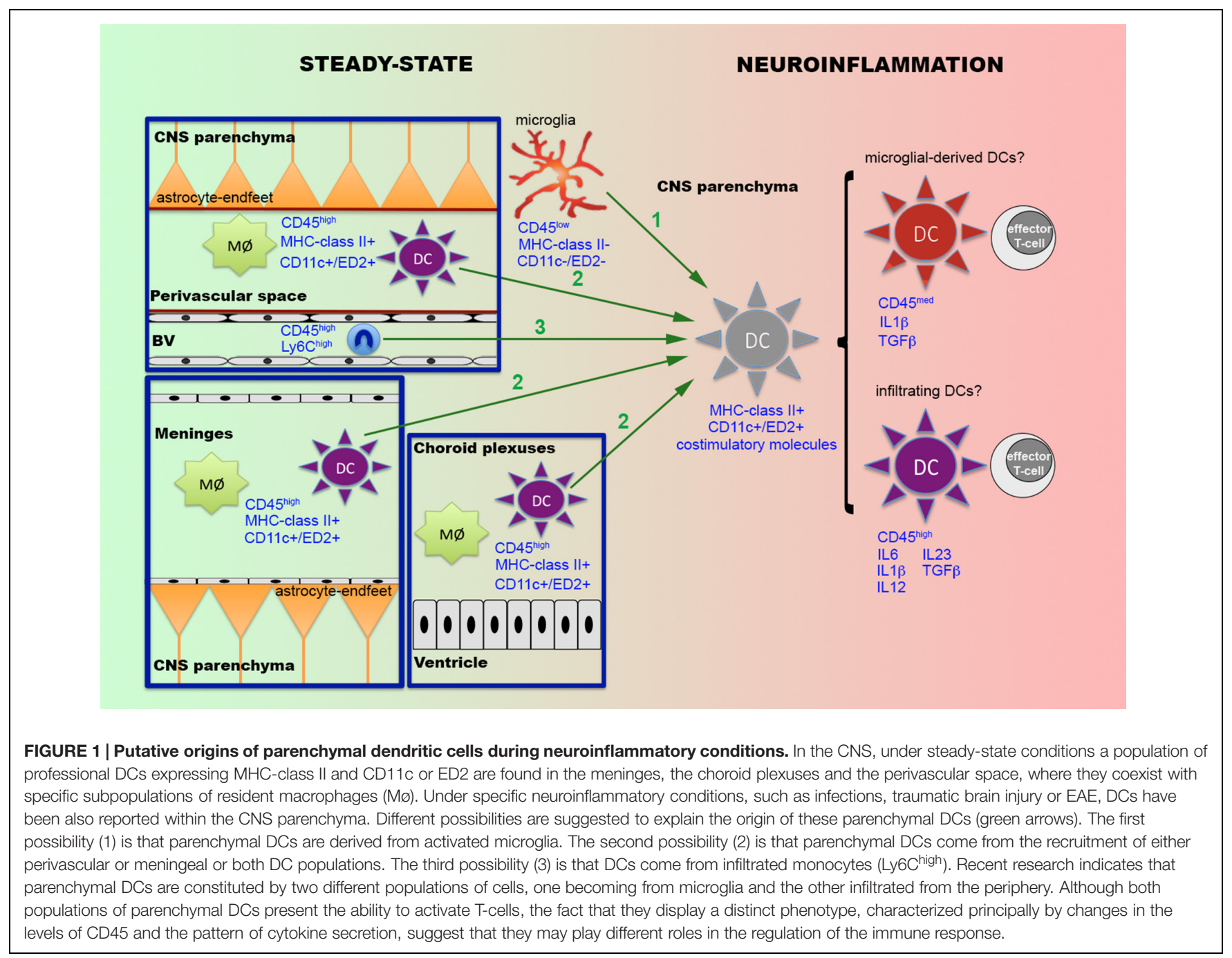


(Figure 1). One possibility suggested by some authors is that the perivascular or meningeal DCs observed in the healthy brain are recruited to inflammatory sites within the CNS parenchyma (McMahon et al., 2006). Alternatively, other authors supported the idea that parenchymal DCs observed during neuroinflammatory conditions come from infiltrated monocytes (Ifergan et al., 2008), which under the influence of specific molecules such as GM-CSF, differentiate to DCs (Ashhurst et al., 2014). Supporting this idea, an alternative developmental circuit occurring after the MDP precursors involves monocytes as precursors of inflammatory DCs in peripheral organs (Dominguez and Ardavin, 2010; Liu and Nussenzweig, 2010). Infiltration of monocytes is a common event in many of the above-mentioned neuroinflammatory situations in which DCs have been described in the CNS parenchyma (Zhu et al., 2007; Serbina et al., 2008; Mildner et al., 2009). Furthermore, systemic administration of GM-CSF in EAEinduced mice mobilizes Ly6 $\mathrm{C}^{\text {high }}$-circulating monocytes that migrate to the CNS parenchyma and are converted into DCs (King et al., 2009). Nevertheless, later studies have demonstrated that intraparenchymal infusion of GM-CSF not only promotes the apparition of DC precursors recruited from the periphery but also induces the emergence of a second population of DCs derived from the CNS with an inhibitory phenotype (Hesske et al., 2010), supporting the idea that DCs not only immigrate from the periphery but may also be derived from local CNS cells.

In this regard, several lines of evidence, including in vitro studies (Fischer and Reichmann, 2001; Butovsky et al., 2007) and neuroinflammatory situations such as ischemia (Kostulas et al., 2002) and EAE (Fischer and Reichmann, 2001; Almolda et al., 2011b; Wlodarczyk et al., 2014), support the hypothesis that parenchymal DCs are derived from the differentiation of local cells, probably microglia, on the basis that the expression of some of the surface antigens commonly used for the identification of DCs, such as CD11c, MHCII and CD86, are found in activated microglial cells. In addition, a study using the CD11c-GFP mouse, which expresses the GFP protein under the control of the CD11c promoter, the pan-marker of DCs, has reported the presence of CD11c+ cells not only in the choroid plexuses and perivascular space but also in the juxtavascular parenchyma of non-lesioned CNS (Prodinger et al., 2010). Interestingly, these authors found that almost all CD11c+ cells in the juxtavascular parenchyma presented markers of microglial cells such as Iba1 and $\mathrm{CD} 11 \mathrm{~b}$, indicating that, presumably, a subpopulation of microglial cells is able to express DC markers in steady-state conditions. Even more, an interesting study (Anandasabapathy et al., 2011) using the Flt3-treatment, a transcription factor involved in the generation of DCs (Waskow et al., 2008; Kingston et al., 2009), to induce the expansion of DCs in transgenic mice carrying the EYFP fluorescent protein under the control of the CD11c promoter, demonstrated the presence of two different populations of CD11c+ cells within healthy CNS. These two populations corresponded to a population of EYFP+ cells located in the choroid plexuses and meninges whose number increased after Flt3 treatment and another discrete population of EYFP+ cells located in CNS parenchyma with ramified morphology whose number remains stable after the treatment. Flow cytometry studies of these two populations demonstrated that the EYFP+ cells in the choroid plexuses and meninges presented a profile of CD $45^{\text {high }} / \mathrm{MHCII}+\mathrm{DCs}$, whereas those EYFP+ cells in the parenchyma corresponds to CD45 int/MHCIImicroglial cells (Anandasabapathy et al., 2011). Furthermore, other works (Wlodarczyk et al., 2014) using flow cytometry for different DCs markers have reported the existence of two populations of DCs in EAE-induced animals in vivo: CD11c+ DCs and CD11c+ microglia. Interestingly, both populations showed a similar ability to induce T-cell proliferation in vitro but, once activated, those T-cells showed a different cytokine profile, suggesting that both populations can play different functions in T-cell activation (Wlodarczyk et al., 2014).

Altogether, these studies indicate, as previously suggested by other authors (Ghosh, 2010), that in addition to professional DCs located in meninges, choroid plexuses and the perivascular space, there is a population of microglial cells that, according to environmental cues, can acquire the phenotype of DCs and consequently may act as professional APCs. One issue to be resolved is if these parenchymal DCs that come from microglia develop the same functions as other DCs or, conversely, if both populations in the CNS have different roles regulating the immune response.

\section{CONCLUDING REMARKS}

Current research suggests that the net effect of the acquired immune response within the CNS must depend not only on the number of lymphocytes and APCs, but must also be directly related to the specific subtype of infiltrated lymphocytes, the particular phenotype of the APC in each situation and the specific micro-environment in which the communication between these two cells takes place. Whether the principal intercomunicators in the cross talk with T-cells are microglial cells, professional DCs or both is an intriguing question, still under discussion, and should be subject to thorough investigation. Research to help clarify the question of the origin and a more complete characterization of the phenotype and function of parenchymal DCs in CNS will offer a more comprehensive understanding of the role played by these cells during the evolution of neuroinflammatory processes.

\section{ACKNOWLEDGMENTS}

The authors would to thank Mr Chuck Simmons, a native, English speaking Instructor of English in the Autonomous University of Barcelona for the proofreading of this manuscript. This work was supported by the Spanish Ministry of Science and Innovation (BFU2011-27400) and the Spanish Ministry of Economy and Competitiveness (BFU2014-55459-p). 


\section{REFERENCES}

Abbas, A., Lichtman, A., and Pillai, S. (2010). Cellular and Molecular Immunology. Philadelphia: Saunders Elsevier.

Almolda, B., Costa, M., Montoya, M., Gonzalez, B., and Castellano, B. (2011a). Increase in Th17 and T-reg lymphocytes and decrease of IL22 correlate with the recovery phase of acute EAE in rat. PLOS ONE 6:e27473. doi: 10.1371/journal.pone.0027473

Almolda, B., Gonzalez, B., and Castellano, B. (2011b). Antigen presentation in EAE: role of microglia, macrophages and dendritic cells. Front. Biosci. (Landmark Ed.) 16:1157-1171.

Almolda, B., Gonzalez, B., and Castellano, B. (2010). Activated microglial cells acquire an immature dendritic cell phenotype and may terminate the immune response in an acute model of EAE. J. Neuroimmunol. 223, 39-54. doi: 10.1016/j.jneuroim.2010.03.021

Aloisi, F. (2001). Immune function of microglia. Glia 36, 165-179. doi: 10.1002/glia.1106

Aloisi, F., Ria, F., and Adorini, L. (2000). Regulation of T-cell responses by CNS antigen-presenting cells: different roles for microglia and astrocytes. Immunol. Today 21, 141-147. doi: 10.1016/S0167-5699(99)01512-1

Anandasabapathy, N., Victora, G. D., Meredith, M., Feder, R., Dong, B., Kluger, C., et al. (2011). Flt3L controls the development of radiosensitive dendritic cells in the meninges and choroid plexus of the steady-state mouse brain. J. Exp. Med. 208, 1695-1705. doi: 10.1084/jem.20102657

Anderson, K. M., Olson, K. E., Estes, K. A., Flanagan, K., Gendelman, H. E., and Mosley, R. L. (2014). Dual destructive and protective roles of adaptive immunity in neurodegenerative disorders. Transl. Neurodegener. 3:25. doi: 10.1186/2047-9158-3-25

Ashhurst, T. M., Van Vreden, C., Niewold, P., and King, N. J. (2014). The plasticity of inflammatory monocyte responses to the inflamed central nervous system. Cell Immunol. 291, 49-57. doi: 10.1016/j.cellimm.2014. 07.002

Babcock, A. A., Toft-Hansen, H., and Owens, T. (2008). Signaling through MyD88 regulates leukocyte recruitment after brain injury. J. Immunol. 181, 6481-6490. doi: 10.4049/jimmunol.181.9.6481

Barker, C. F., and Billingham, R. E. (1977). Immunologically privileged sites. $A d v$. Immunol. 25, 1-54. doi: 10.1016/S0065-2776(08)60930-X

Becher, B., Bechmann, I., and Greter, M. (2006). Antigen presentation in autoimmunity and CNS inflammation: how T lymphocytes recognize the brain. J. Mol. Med. (Berl.) 84, 532-543. doi: 10.1007/s00109-006-0065-1

Becher, B., Durell, B. G., Miga, A. V., Hickey, W. F., and Noelle, R. J. (2001). The clinical course of experimental autoimmune encephalomyelitis and inflammation is controlled by the expression of CD40 within the central nervous system. J. Exp. Med. 193, 967-974. doi: 10.1084/jem.193.8.967

Becher, B., Prat, A., and Antel, J. P. (2000). Brain-immune connection: immuno-regulatory properties of CNS-resident cells. Glia 29, 293-304. doi: 10.1002/(SICI)1098-1136(20000215)29:4<293::AID-GLIA1>3.3.CO;2-1

Bechmann, I., Mor, G., Nilsen, J., Eliza, M., Nitsch, R., and Naftolin, F. (1999). FasL (CD95L, Apo1L) is expressed in the normal rat and human brain: evidence for the existence of an immunological brain barrier. Glia 27, 62-74. doi: 10.1002/(SICI)1098-1136(199907)27:1<62::AID-GLIA7> 3.0.CO;2-S

Bechmann, I., Peter, S., Beyer, M., Gimsa, U., and Nitsch, R. (2001). Presence of B7-2 (CD86) and lack of B7-1 (CD (80) on myelin phagocytosing MHCII-positive rat microglia is associated with nondestructive immunity in vivo. FASEB J. 15, 1086-1088.

Beers, D. R., Henkel, J. S., Zhao, W., Wang, J., and Appel, S. H. (2008). CD4+ T cells support glial neuroprotection, slow disease progression, and modify glial morphology in an animal model of inherited ALS. Proc. Natl. Acad. Sci. U.S.A. 105, 15558-15563. doi: 10.1073/pnas.0807419105

Bluestone, J. A., and Tang, Q. (2005). How do $\mathrm{CD}^{+} \mathrm{CD} 25^{+}$regulatory $\mathrm{T}$ cells control autoimmunity? Curr. Opin. Immunol. 17, 638-642. doi: 10.1016/j.coi.2005.09.002

Bodhankar, S., Chen, Y., Vandenbark, A. A., Murphy, S. J., and Offner, H. (2013). PD-L1 enhances CNS inflammation and infarct volume following experimental stroke in mice in opposition to PD-1. J. Neuroinflamm. 10, 111. doi: 10.1186/1742-2094-10-111

Bohatschek, M., Kloss, C. U., Pfeffer, K., Bluethmann, H., and Raivich, G. (2004). B7.2 on activated and phagocytic microglia in the facial axotomy model: regulation by interleukin-1 receptor type 1 , tumor necrosis factor receptors 1 and 2 and endotoxin. J. Neuroimmunol. 156, 132-145. doi: 10.1016/j.jneuroim.2004.07.018

Brochard, V., Combadiere, B., Prigent, A., Laouar, Y., Perrin, A., Beray-Berthat, V., et al. (2009). Infiltration of $\mathrm{CD}^{+}$lymphocytes into the brain contributes to neurodegeneration in a mouse model of Parkinson disease. J. Clin. Invest. 119, 182-192. doi: 10.1172/JCI36470

Butovsky, O., Bukshpan, S., Kunis, G., Jung, S., and Schwartz, M. (2007). Microglia can be induced by IFN-gamma or IL-4 to express neural or dendriticlike markers. Mol. Cell Neurosci. 35, 490-500. doi: 10.1016/j.mcn.2007. 04.009

Carson, M. J. (2002). Microglia as liaisons between the immune and central nervous systems: functional implications for multiple sclerosis. Glia 40, 218 231. doi: $10.1002 /$ glia. 10145

Casano, A. M., and Peri, F. (2015). Microglia: multitasking specialists of the brain. Dev. Cell 32, 469-477. doi: 10.1016/j.devcel.2015.01.018

Castellano, B., Bosch, M., Almolda, B., Villacampa, N., and Gonzalez, B. (2015). "Purine signaling and microglial wrapping," in Glial Cells in Health and Disease, eds R. von Bernhardi and K. Muller (Berlin: Springer), in press.

Chen, K., Huang, J., Gong, W., Zhang, L., Yu, P., and Wang, J. M. (2006). CD40/CD40L dyad in the inflammatory and immune responses in the central nervous system. Cell Mol. Immunol. 3, 163-169.

Chen, L., and Flies, D. B. (2013). Molecular mechanisms of T cell costimulation and co-inhibition. Nat. Rev. Immunol. 13, 227-242. doi: 10.1038/ nri3405

Chen, Z., and Trapp, B. D. (2015). Microglia and neuroprotection. J. Neurochem. doi: 10.1111/jnc.13062 [Epub ahead of print].

Chiu, I. M., Chen, A., Zheng, Y., Kosaras, B., Tsiftsoglou, S. A., Vartanian, T. K., et al. (2008). T lymphocytes potentiate endogenous neuroprotective inflammation in a mouse model of ALS. Proc. Natl. Acad. Sci. U.S.A. 105, 17913-17918. doi: 10.1073/pnas.0804610105

Colton, C. A. (2012). Immune heterogeneity in neuroinflammation: dendritic cells in the brain. J. Neuroimmune Pharmacol. 8, 145-162. doi: 10.1007/s11481-0129414-8

Cosmi, L., Maggi, L., Santarlasci, V., Liotta, F., and Annunziato, F. (2014). $\mathrm{T}$ helper cells plasticity in inflammation. Cytometry $A$ 85, 36-42. doi: 10.1002/cyto.a.22348

Cuadros, M. A., and Navascues, J. (1998). The origin and differentiation of microglial cells during development. Prog. Neurobiol. 56, 173-189. doi: 10.1016/S0301-0082(98)00035-5

Curotto de Lafaille, M. A., and Lafaille, J. J. (2009). Natural and adaptive foxp3 ${ }^{+}$ regulatory $\mathrm{T}$ cells: more of the same or a division of labor? Immunity 30, 626-635. doi: 10.1016/j.immuni.2009.05.002

D’Agostino, P. M., Gottfried-Blackmore, A., Anandasabapathy, N., and Bulloch, K. (2012). Brain dendritic cells: biology and pathology. Acta Neuropathol. 124, 599-614. doi: 10.1007/s00401-012-1018-0

Dalmau, I., Finsen, B., Zimmer, J., Gonzalez, B., and Castellano, B. (1998). Development of microglia in the postnatal rat hippocampus. Hippocampus 8, 458-474. doi: 10.1002/(SICI)1098-1063(1998)8:5<458::AIDHIPO6>3.3.CO;2-E

Dalmau, I., Vela, J. M., Gonzalez, B., Finsen, B., and Castellano, B. (2003). Dynamics of microglia in the developing rat brain. J. Comp. Neurol. 458, 144-157. doi: $10.1002 /$ cne.10572

Davalos, D., Grutzendler, J., Yang, G., Kim, J. V., Zuo, Y., Jung, S., et al. (2005). ATP mediates rapid microglial response to local brain injury in vivo. Nat. Neurosci. 8, 752-758. doi: 10.1038/nn1472

D'Aversa, T. G., Eugenin, E. A., and Berman, J. W. (2005). NeuroAIDS: contributions of the human immunodeficiency virus- 1 proteins Tat and gp 120 as well as CD40 to microglial activation. J. Neurosci. Res. 81, 436-446. doi: 10.1002/jnr.20486

D’Aversa, T. G., Weidenheim, K. M., and Berman, J. W. (2002). CD40-CD40L interactions induce chemokine expression by human microglia: implications for human immunodeficiency virus encephalitis and multiple sclerosis. Am. J. Pathol. 160, 559-567. doi: 10.1016/S0002-9440(10)64875-4

Deaglio, S., Dwyer, K. M., Gao, W., Friedman, D., Usheva, A., Erat, A., et al. (2007). Adenosine generation catalyzed by CD39 and CD73 expressed on regulatory T cells mediates immune suppression. J. Exp. Med. 204, 1257-1265. doi: $10.1084 /$ jem.20062512 
Dittel, B. N. (2008). CD4 T cells: balancing the coming and going of autoimmunemediated inflammation in the CNS. Brain Behav. Immun. 22, 421-430. doi: 10.1016/j.bbi.2007.11.010

Dominguez, P. M., and Ardavin, C. (2010). Differentiation and function of mouse monocyte-derived dendritic cells in steady state and inflammation. Immunol. Rev. 234, 90-104. doi: 10.1111/j.0105-2896.2009.00876.x

Duncan, D. S., and Miller, S. D. (2011). CNS expression of B7-H1 regulates proinflammatory cytokine production and alters severity of Theiler's virus-induced demyelinating disease. PLOS ONE 6:e18548. doi: 10.1371/journal.pone.00 18548

Eggen, B. J., Raj, D., Hanisch, U. K., and Boddeke, H. W. (2013). Microglial phenotype and adaptation. J. Neuroimmune Pharmacol. 8, 807-823. doi: 10.1007/s11481-013-9490-4

Eltzschig, H. K., Sitkovsky, M. V., and Robson, S. C. (2012). Purinergic signaling during inflammation. N. Engl. J. Med. 367, 2322-2333. doi: 10.1056/NEJMra1205750

Engelhardt, B. (2006). Molecular mechanisms involved in T cell migration across the blood-brain barrier. J. Neural. Transm. 113, 477-485. doi: 10.1007/s00702005-0409-y

Engelhardt, B. (2008). Immune cell entry into the central nervous system: involvement of adhesion molecules and chemokines. J. Neurol. Sci. 274, 23-26. doi: 10.1016/j.jns.2008.05.019

Engelhardt, B., and Ransohoff, R. M. (2005). The ins and outs of T-lymphocyte trafficking to the CNS: anatomical sites and molecular mechanisms. Trends Immunol. 26, 485-495. doi: 10.1016/j.it.2005.07.004

Felger, J. C., Abe, T., Kaunzner, U. W., Gottfried-Blackmore, A., Gal-Toth, J., Mcewen, B. S., et al. (2009). Brain dendritic cells in ischemic stroke: time course, activation state, and origin. Brain Behav. Immun. 24, 724-737. doi: 10.1016/j.bbi.2009.11.002

Finsen, B. R., Jorgensen, M. B., Diemer, N. H., and Zimmer, J. (1993). Microglial MHC antigen expression after ischemic and kainic acid lesions of the adult rat hippocampus. Glia 7, 41-49. doi: 10.1002/glia.440070109

Fischer, H. G., and Reichmann, G. (2001). Brain dendritic cells and macrophages/microglia in central nervous system inflammation. J. Immunol. 166, 2717-2726. doi: 10.4049/jimmunol.166.4.2717

Flugel, A., Schwaiger, F. W., Neumann, H., Medana, I., Willem, M., Wekerle, H., et al. (2000). Neuronal FasL induces cell death of encephalitogenic $\mathrm{T}$ lymphocytes. Brain Pathol. 10, 353-364. doi: 10.1111/j.1750-3639.2000.tb00267.x

Gelderblom, M., Leypoldt, F., Steinbach, K., Behrens, D., Choe, C. U., Siler, D. A., et al. (2009). Temporal and spatial dynamics of cerebral immune cell accumulation in stroke. Stroke 40, 1849-1857. doi: 10.1161/STROKEAHA.108.534503

Ghosh, A. (2010). Brain APCs including microglia are only differential and positional polymorphs. Ann. Neurosci. 17, 191-199. doi: 10.5214/ans.0972.7531.1017410

Ginhoux, F., Greter, M., Leboeuf, M., Nandi, S., See, P., Gokhan, S., et al. (2010). Fate mapping analysis reveals that adult microglia derive from primitive macrophages. Science 330, 841-845. doi: 10.1126/science.1194637

Ginhoux, F., Lim, S., Hoeffel, G., Low, D., and Huber, T. (2013). Origin and differentiation of microglia. Front. Cell Neurosci. 7:45. doi: 10.3389/fncel.2013.00045

Glass, W. G., Lim, J. K., Cholera, R., Pletnev, A. G., Gao, J. L., and Murphy, P. M. (2005). Chemokine receptor CCR5 promotes leukocyte trafficking to the brain and survival in West Nile virus infection. J. Exp. Med. 202, 1087-1098. doi: 10.1084/jem.20042530

Goldmann, T., and Prinz, M. (2013). Role of microglia in CNS autoimmunity. Clin. Dev. Immunol. 2013:208093. doi: 10.1155/2013/208093

Gonzalez, H., Elgueta, D., Montoya, A., and Pacheco, R. (2014). Neuroimmune regulation of microglial activity involved in neuroinflammation and neurodegenerative diseases. J. Neuroimmunol. 274, 1-13. doi: 10.1016/j.jneuroim.2014.07.012

Graeber, M. B., and Streit, W. J. (2010). Microglia: biology and pathology. Acta Neuropathol. 119, 89-105. doi: 10.1007/s00401-009-0622-0

Grauer, O. M., Nierkens, S., Bennink, E., Toonen, L. W., Boon, L., Wesseling, P., et al. (2007). CD4+FoxP3+ regulatory T cells gradually accumulate in gliomas during tumor growth and efficiently suppress antiglioma immune responses in vivo. Int. J. Cancer 121, 95-105. doi: 10.1002/ijc.22607
Griffin, R., Nally, R., Nolan, Y., Mccartney, Y., Linden, J., and Lynch, M. A. (2006). The age-related attenuation in long-term potentiation is associated with microglial activation. J. Neurochem. 99, 1263-1272. doi: 10.1111/j.14714159.2006.04165.x

Guermonprez, P., Valladeau, J., Zitvogel, L., Thery, C., and Amigorena, S. (2002). Antigen presentation and $\mathrm{T}$ cell stimulation by dendritic cells. Annu. Rev. Immunol. 20, 621-667. doi: 10.1146/annurev.immunol.20.100301.064828

Hanisch, U. K. (2013). Functional diversity of microglia - how heterogeneous are they to begin with? Front. Cell Neurosci. 7:65. doi: 10.3389/fncel.2013.00065

Harry, G. J., and Kraft, A. D. (2012). Microglia in the developing brain: a potential target with lifetime effects. Neurotoxicology 33, 191-206. doi: 10.1016/j.neuro.2012.01.012

Henkel, J. S., Engelhardt, J. I., Siklos, L., Simpson, E. P., Kim, S. H., Pan, T., et al. (2004). Presence of dendritic cells, MCP-1, and activated microglia/macrophages in amyotrophic lateral sclerosis spinal cord tissue. Ann. Neurol. 55, 221-235. doi: 10.1002/ana.10805

Hesske, L., Vincenzetti, C., Heikenwalder, M., Prinz, M., Reith, W., Fontana, A., et al. (2010). Induction of inhibitory central nervous system-derived and stimulatory blood-derived dendritic cells suggests a dual role for granulocytemacrophage colony-stimulating factor in central nervous system inflammation. Brain 133, 1637-1654. doi: 10.1093/brain/awq081

Holmoy, T. (2008). T cells in amyotrophic lateral sclerosis. Eur. J. Neurol. 15, 360-366. doi: 10.1111/j.1468-1331.2008.02065.x

Horwitz, D. A., Zheng, S. G., and Gray, J. D. (2008). Natural and TGF-beta-induced Foxp3(+)CD4(+) CD25(+) regulatory $\mathrm{T}$ cells are not mirror images of each other. Trends Immunol. 29, 429-435. doi: 10.1016/j.it.2008.06.005

Huang, Y. M., Yang, J. S., Xu, L. Y., Link, H., and Xiao, B. G. (2000). Autoantigen-pulsed dendritic cells induce tolerance to experimental allergic encephalomyelitis (EAE) in Lewis rats. Clin. Exp. Immunol. 122, 437-444. doi: 10.1046/j.1365-2249.2000.01398.x

Ifergan, I., Kebir, H., Bernard, M., Wosik, K., Dodelet-Devillers, A., Cayrol, R., et al. (2008). The blood-brain barrier induces differentiation of migrating monocytes into Th17-polarizing dendritic cells. Brain 131, 785-799. doi: 10.1093/brain/awm295

Israelsson, C., Bengtsson, H., Lobell, A., Nilsson, L. N., Kylberg, A., Isaksson, M., et al. (2010). Appearance of Cxcl10-expressing cell clusters is common for traumatic brain injury and neurodegenerative disorders. Eur. J. Neurosci. 31, 852-863. doi: 10.1111/j.1460-9568.2010.07105.x

Issazadeh, S., Navikas, V., Schaub, M., Sayegh, M., and Khoury, S. (1998). Kinetics of expression of costimulatory molecules and their ligands in murine relapsing experimental autoimmune encephalomyelitis in vivo. J. Immunol. 161, 11041112.

Jin, Y. H., Hou, W., Kang, H. S., Koh, C. S., and Kim, B. S. (2013). The role of interleukin-6 in the expression of PD-1 and PDL-1 on central nervous system cells following infection with Theiler's murine encephalomyelitis virus. J. Virol. 87, 11538-11551. doi: 10.1128/JVI.01967-13

Juedes, A. E., and Ruddle, N. H. (2001). Resident and infiltrating central nervous system APCs regulate the emergence and resolution of experimental autoimmune encephalomyelitis. J. Immunol. 166, 5168-5175. doi: 10.4049/jimmunol.166.8.5168

Kaunzner, U. W., Miller, M. M., Gottfried-Blackmore, A., Gal-Toth, J., Felger, J. C., Mcewen, B. S., et al. (2010). Accumulation of resident and peripheral dendritic cells in the aging CNS. Neurobiol. Aging 33, 681.e1-693.e1. doi: 10.1016/j.neurobiolaging.2010.06.007

Ke, Z. J., Calingasan, N. Y., Degiorgio, L. A., Volpe, B. T., and Gibson, G. E. (2005). CD40-CD40L interactions promote neuronal death in a model of neurodegeneration due to mild impairment of oxidative metabolism. Neurochem. Int. 47, 204-215. doi: 10.1016/j.neuint.2005.03.002

Kettenmann, H., Hanisch, U. K., Noda, M., and Verkhratsky, A. (2011). Physiology of microglia. Physiol. Rev. 91, 461-553. doi: 10.1152/physrev.00011.2010

Kierdorf, K., and Prinz, M. (2013). Factors regulating microglia activation. Front. Cell Neurosci. 7:44. doi: 10.3389/fncel.2013.00044

King, I. L., Dickendesher, T. L., and Segal, B. M. (2009). Circulating Ly-6C+ myeloid precursors migrate to the CNS and play a pathogenic role during autoimmune demyelinating disease. Blood 113, 3190-3197. doi: 10.1182/blood2008-07-168575

Kingston, D., Schmid, M. A., Onai, N., Obata-Onai, A., Baumjohann, D., and Manz, M. G. (2009). The concerted action of GM-CSF and Flt3-ligand on 
in vivo dendritic cell homeostasis. Blood 114, 835-843. doi: 10.1182/blood2009-02-206318

Kishimoto, H., and Sprent, J. (1999). Strong TCR ligation without costimulation causes rapid onset of Fas-dependent apoptosis of naive murine CD4+ T cells. J. Immunol. 163, 1817-1826.

Kohm, A. P., Mcmahon, J. S., Podojil, J. R., Begolka, W. S., Degutes, M., Kasprowicz, D. J., et al. (2006). Cutting Edge: anti-CD25 monoclonal antibody injection results in the functional inactivation, not depletion, of $\mathrm{CD} 4+\mathrm{CD} 25+\mathrm{T}$ regulatory cells. J. Immunol. 176, 3301-3305. doi: 10.4049/jimmunol.176.6.3301

Korn, T., Anderson, A. C., Bettelli, E., and Oukka, M. (2007). The dynamics of effector $\mathrm{T}$ cells and Foxp3+ regulatory $\mathrm{T}$ cells in the promotion and regulation of autoimmune encephalomyelitis. J. Neuroimmunol. 191, 51-60. doi: 10.1016/j.jneuroim.2007.09.009

Kostulas, N., Li, H. L., Xiao, B. G., Huang, Y. M., Kostulas, V., and Link, H. (2002). Dendritic cells are present in ischemic brain after permanent middle cerebral artery occlusion in the rat. Stroke 33, 1129-1134. doi: 10.1161/hs0402. 105379

Kreutzberg, G. W. (1996). Microglia: a sensor for pathological events in the CNS. Trends Neurosci. 19, 312-318. doi: 10.1016/0166-2236(96) 10049-7

Kwidzinski, E., Bunse, J., Aktas, O., Richter, D., Mutlu, L., Zipp, F., et al. (2005). Indolamine 2,3-dioxygenase is expressed in the CNS and down-regulates autoimmune inflammation. FASEB J. 19, 1347-1349.

Kwidzinski, E., Bunse, J., Kovac, A. D., Ullrich, O., Zipp, F., Nitsch, R., et al. (2003a). IDO (indolamine 2,3-dioxygenase) expression and function in the CNS. Adv. Exp. Med. Biol. 527, 113-118. doi: 10.1007/978-1-4615-0135-0_13

Kwidzinski, E., Mutlu, L. K., Kovac, A. D., Bunse, J., Goldmann, J., Mahlo, J., et al. (2003b). Self-tolerance in the immune privileged CNS: lessons from the entorhinal cortex lesion model. J. Neural Transm. Suppl. 65, 29-49. doi: 10.1007/978-3-7091-0643-3_2

Lanzavecchia, A. (1997). Understanding the mechanisms of sustained signaling and T cell activation. J. Exp. Med. 185, 1717-1719. doi: 10.1084/jem.185.10.1717

Lin, H. W., Jain, M. R., Li, H., and Levison, S. W. (2009). Ciliary neurotrophic factor (CNTF) plus soluble CNTF receptor alpha increases cyclooxygenase2 expression, PGE2 release and interferon-gamma-induced CD40 in murine microglia. J. Neuroinflamm. 6:7. doi: 10.1186/1742-2094-6-7

Lin, H. W., and Levison, S. W. (2009). Context-dependent IL-6 potentiation of interferon- gamma-induced IL-12 secretion and CD40 expression in murine microglia. J. Neurochem. 111, 808-818. doi: 10.1111/j.1471-4159.2009.0 6366.x

Lipp, M., Brandt, C., Dehghani, F., Kwidzinski, E., and Bechmann, I. (2007). PDL1 (B7-H1) regulation in zones of axonal degeneration. Neurosci. Lett. 425, 156-161. doi: 10.1016/j.neulet.2007.07.053

Liu, K., and Nussenzweig, M. C. (2010). Origin and development of dendritic cells. Immunol. Rev. 234, 45-54. doi: 10.1111/j.0105-2896.2009.00879.x

Mack, C. L., Vanderlugt-Castaneda, C. L., Neville, K. L., and Miller, S. D. (2003). Microglia are activated to become competent antigen presenting and effector cells in the inflammatory environment of the Theiler's virus model of multiple sclerosis. J. Neuroimmunol. 144, 68-79. doi: 10.1016/j.jneuroim.2003. 08.032

Mascanfroni, I. D., Yeste, A., Vieira, S. M., Burns, E. J., Patel, B., Sloma, I., et al. (2013). IL-27 acts on DCs to suppress the T cell response and autoimmunity by inducing expression of the immunoregulatory molecule CD39. Nat. Immunol. 14, 1054-1063. doi: 10.1038/ni.2695

Matyszak, M. K., and Perry, V. H. (1996). The potential role of dendritic cells in immune-mediated inflammatory diseases in the central nervous system. Neuroscience 74, 599-608. doi: 10.1016/0306-4522(96)00160-1

Matyszak, M. K., and Perry, V. H. (1998). Bacillus Calmette-Guerin sequestered in the brain parenchyma escapes immune recognition. J. Neuroimmunol. 82, 73-80. doi: 10.1016/S0165-5728(97)00190-2

McGeachy, M. J., Stephens, L. A., and Anderton, S. M. (2005). Natural recovery and protection from autoimmune encephalomyelitis: contribution of CD4+CD25+ regulatory cells within the central nervous system. J. Immunol. 175, 3025-3032. doi: 10.4049/jimmunol.175.5.3025

McMahon, E. J., Bailey, S. L., and Miller, S. D. (2006). CNS dendritic cells: critical participants in CNS inflammation? Neurochem. Int. 49, 195-203. doi: 10.1016/j.neuint.2006.04.004
McMenamin, P. G. (1999). Distribution and phenotype of dendritic cells and resident tissue macrophages in the dura mater, leptomeninges, and choroid plexus of the rat brain as demonstrated in wholemount preparations. J. Comp. Neurol. 405, 553-562. doi: 10.1002/(SICI)10969861(19990322)405:4<553::AID-CNE8 > 3.3.CO;2-Y

McMenamin, P. G., Wealthall, R. J., Deverall, M., Cooper, S. J., and Griffin, B. (2003). Macrophages and dendritic cells in the rat meninges and choroid plexus: three-dimensional localisation by environmental scanning electron microscopy and confocal microscopy. Cell Tissue Res. 313, 259-269. doi: 10.1007/s00441003-0779-0

Medawar, P. B. (1948). Immunity to homologous grafted skin; the fate of skin homografts transplanted to the brain, to subcutaneous tissue, and to the anterior chamber of the eye. Br. J. Exp. Pathol. 29, 58-69.

Mildner, A., Mack, M., Schmidt, H., Bruck, W., Djukic, M., Zabel, M. D., et al. (2009). CCR2+Ly-6Chi monocytes are crucial for the effector phase of autoimmunity in the central nervous system. Brain 132, 2487-2500. doi: 10.1093/brain/awp144

Navascues, J., Calvente, R., Marin-Teva, J. L., and Cuadros, M. A. (2000). Entry, dispersion and differentiation of microglia in the developing central nervous system. An. Acad. Bras. Cienc. 72, 91-102. doi: 10.1590/S000137652000000100013

Newman, T. A., Galea, I., Van Rooijen, N., and Perry, V. H. (2005). Blood-derived dendritic cells in an acute brain injury. J. Neuroimmunol. 166, 167-172. doi: 10.1016/j.jneuroim.2005.04.026

Ng, Y. K., and Ling, E. A. (1997). Induction of major histocompatibility class II antigen on microglial cells in postnatal and adult rats following intraperitoneal injections of lipopolysaccharide. Neurosci. Res. 28, 111-118. doi: 10.1016/S0168-0102(97)00033-3

Nimmerjahn, A., Kirchhoff, F., and Helmchen, F. (2005). Resting microglial cells are highly dynamic surveillants of brain parenchyma in vivo. Science 308, 1314-1318. doi: 10.1126/science.1110647

Nurieva, R. I., Liu, X., and Dong, C. (2009). Yin-Yang of costimulation: crucial controls of immune tolerance and function. Immunol. Rev. 229, 88-100. doi: 10.1111/j.1600-065X.2009.00769.x

Okuno, T., Nakatsuji, Y., Kumanogoh, A., Koguchi, K., Moriya, M., Fujimura, H., et al. (2004). Induction of cyclooxygenase- 2 in reactive glial cells by the CD40 pathway: relevance to amyotrophic lateral sclerosis. J. Neurochem. 91, 404-412. doi: 10.1111/j.1471-4159.2004.02727.x

Olson, J. K., Girvin, A. M., and Miller, S. D. (2001). Direct activation of innate and antigen-presenting functions of microglia following infection with Theiler's virus. J. Virol. 75, 9780-9789. doi: 10.1128/JVI.75.20.9780-9789. 2001

Ousman, S. S., and Kubes, P. (2012). Immune surveillance in the central nervous system. Nat. Neurosci. 15, 1096-1101. doi: 10.1038/nn.3161

Perry, V. H. (1998). A revised view of the central nervous system microenvironment and major histocompatibility complex class II antigen presentation. J. Neuroimmunol. 90, 113-121. doi: 10.1016/S0165-5728(98)00145-3

Petito, C. K., Adkins, B., Mccarthy, M., Roberts, B., and Khamis, I. (2003). CD4+ and CD8+ cells accumulate in the brains of acquired immunodeficiency syndrome patients with human immunodeficiency virus encephalitis. J. Neurovirol. 9, 36-44. doi: 10.1080/135502803901 73391

Phares, T. W., Ramakrishna, C., Parra, G. I., Epstein, A., Chen, L., Atkinson, R., et al. (2009). Target-dependent B7-H1 regulation contributes to clearance of central nervous system infection and dampens morbidity. J. Immunol. 182, 5430-5438. doi: 10.4049/jimmunol.0803557

Piccioni, M., Chen, Z., Tsun, A., and Li, B. (2014). Regulatory T-cell differentiation and their function in immune regulation. Adv. Exp. Med. Biol. 841, 67-97. doi: 10.1007/978-94-017-9487-9_4

Plumb, J., Armstrong, M. A., Duddy, M., Mirakhur, M., and Mcquaid, S. (2003). CD83-positive dendritic cells are present in occasional perivascular cuffs in multiple sclerosis lesions. Mult. Scler. 9, 142-147. doi: 10.1191/1352458503ms890oa

Ponomarev, E. D., Shriver, L. P., and Dittel, B. N. (2006). CD40 expression by microglial cells is required for their completion of a two-step activation process during central nervous system autoimmune inflammation. J. Immunol. 176, 1402-1410. doi: 10.4049/jimmunol.176.3.1402 
Pont-Lezica, L., Bechade, C., Belarif-Cantaut, Y., Pascual, O., and Bessis, A. (2011). Physiological roles of microglia during development. J. Neurochem. 119, 901908. doi: 10.1111/j.1471-4159.2011.07504.x

Prinz, M., Tay, T. L., Wolf, Y., and Jung, S. (2014). Microglia: unique and common features with other tissue macrophages. Acta Neuropathol. 128, 319-331. doi: 10.1007/s00401-014-1267-1

Prodinger, C., Bunse, J., Kruger, M., Schiefenhovel, F., Brandt, C., Laman, J. D., et al. (2010). CD11c-expressing cells reside in the juxtavascular parenchyma and extend processes into the glia limitans of the mouse nervous system. Acta Neuropathol. 121, 445-458. doi: 10.1007/s00401-010-0774-y

Qin, H., Wilson, C. A., Lee, S. J., Zhao, X., and Benveniste, E. N. (2005). LPS induces CD40 gene expression through the activation of NF-kappaB and STAT-1alpha in macrophages and microglia. Blood 106, 3114-3122. doi: 10.1182/blood-200502-0759

Raivich, G., and Banati, R. (2004). Brain microglia and blood-derived macrophages: molecular profiles and functional roles in multiple sclerosis and animal models of autoimmune demyelinating disease. Brain Res. Brain Res. Rev. 46, 261-281. doi: 10.1016/j.brainresrev.2004.06.006

Raivich, G., Jones, L. L., Kloss, C. U., Werner, A., Neumann, H., and Kreutzberg, G. W. (1998). Immune surveillance in the injured nervous system: T-lymphocytes invade the axotomized mouse facial motor nucleus and aggregate around sites of neuronal degeneration. J. Neurosci. 18, 5804-5816.

Ransohoff, R. M., and Cardona, A. E. (2010). The myeloid cells of the central nervous system parenchyma. Nature 468, 253-262. doi: 10.1038/nature09615

Ransohoff, R. M., and Engelhardt, B. (2012). The anatomical and cellular basis of immune surveillance in the central nervous system. Nat. Rev. Immunol. 12, 623-635. doi: 10.1038/nri3265

Ransohoff, R. M., Kivisakk, P., and Kidd, G. (2003). Three or more routes for leukocyte migration into the central nervous system. Nat. Rev. Immunol. 3, 569-581. doi: 10.1038/nri1130

Reichmann, G., Schroeter, M., Jander, S., and Fischer, H. G. (2002). Dendritic cells and dendritic-like microglia in focal cortical ischemia of the mouse brain. J. Neuroimmunol. 129, 125-132. doi: 10.1016/S0165-5728(02)00184-4

Reinhardt, R. L., Kang, S. J., Liang, H. E., and Locksley, R. M. (2006). T helper cell effector fates-who, how and where? Curr. Opin. Immunol. 18, 271-277. doi: 10.1016/j.coi.2006.03.003

Remington, L. T., Babcock, A. A., Zehntner, S. P., and Owens, T. (2007). Microglial recruitment, activation, and proliferation in response to primary demyelination. Am. J. Pathol. 170, 1713-1724. doi: 10.2353/ajpath.2007.060783

Ren, X., Akiyoshi, K., Vandenbark, A. A., Hurn, P. D., and Offner, H. (2011). Programmed death-1 pathway limits central nervous system inflammation and neurologic deficits in murine experimental stroke. Stroke 42, 2578-2583. doi: 10.1161/STROKEAHA.111.613182

Rezai-Zadeh, K., Gate, D., and Town, T. (2009). CNS infiltration of peripheral immune cells: D-Day for neurodegenerative disease? J. Neuroimmune Pharmacol. 4, 462-475. doi: 10.1007/s11481-009-9166-2

Rottman, J. B., Smith, T., Tonra, J. R., Ganley, K., Bloom, T., Silva, R., et al. (2001). The costimulatory molecule ICOS plays an important role in the immunopathogenesis of EAE. Nat. Immunol. 2, 605-611. doi: 10.1038/89750

Rutkowski, M. D., Lambert, F., Raghavendra, V., and Deleo, J. A. (2004). Presence of spinal B7.2 (CD86) but not B7.1 (CD80) co-stimulatory molecules following peripheral nerve injury: role of nondestructive immunity in neuropathic pain. J. Neuroimmunol. 146, 94-98. doi: 10.1016/j.jneuroim.2003.10.055

Salama, A. D., Chitnis, T., Imitola, J., Ansari, M. J., Akiba, H., Tushima, F., et al. (2003). Critical role of the programmed death-1 (PD-1) pathway in regulation of experimental autoimmune encephalomyelitis. J. Exp. Med. 198, 71-78. doi: 10.1084/jem.20022119

Sansom, D. M. (2000). CD28, CTLA-4 and their ligands: who does what and to whom? Immunology 101, 169-177. doi: 10.1046/j.1365-2567.2000.00121.x

Santambrogio, L., Belyanskaya, S. L., Fischer, F. R., Cipriani, B., Brosnan, C. F., Ricciardi-Castagnoli, P., et al. (2001). Developmental plasticity of CNS microglia. Proc. Natl. Acad. Sci. U.S.A. 98, 6295-6300. doi: 10.1073/pnas.111152498

Santambrogio, L., and Strominger, J. L. (2006). The ins and outs of MHC class II proteins in dendritic cells. Immunity 25, 857-859. doi: 10.1016/j.immuni.2006.11.007

Schreiner, B., Bailey, S. L., Shin, T., Chen, L., and Miller, S. D. (2008). PD1 ligands expressed on myeloid-derived APC in the CNS regulate T-cell responses in EAE. Eur. J. Immunol. 38, 2706-2717. doi: 10.1002/eji.20083 8137

Schroeter, M., Jander, S., Witte, O. W., and Stoll, G. (1994). Local immune responses in the rat cerebral cortex after middle cerebral artery occlusion. J. Neuroimmunol. 55, 195-203. doi: 10.1016/0165-5728(94)90010-8

Schulz, C., Gomez Perdiguero, E., Chorro, L., Szabo-Rogers, H., Cagnard, N., Kierdorf, K., et al. (2012). A lineage of myeloid cells independent of Myb and hematopoietic stem cells. Science 336, 86-90. doi: 10.1126/science.121 9179

Sedgwick, J. D., Ford, A. L., Foulcher, E., and Airriess, R. (1998). Central nervous system microglial cell activation and proliferation follows direct interaction with tissue-infiltrating T cell blasts. J. Immunol. 160, 5320-5330.

Serafini, B., Columba-Cabezas, S., Di Rosa, F., and Aloisi, F. (2000). Intracerebral recruitment and maturation of dendritic cells in the onset and progression of experimental autoimmune encephalomyelitis. Am. J. Pathol. 157, 1991-2002. doi: 10.1016/S0002-9440(10)64838-9

Serafini, B., Rosicarelli, B., Magliozzi, R., Stigliano, E., Capello, E., Mancardi, G. L., et al. (2006). Dendritic cells in multiple sclerosis lesions: maturation stage, myelin uptake, and interaction with proliferating T cells. J. Neuropathol. Exp. Neurol. 65, 124-141.

Serbina, N. V., Jia, T., Hohl, T. M., and Pamer, E. G. (2008). Monocyte-mediated defense against microbial pathogens. Annu. Rev. Immunol. 26, 421-452. doi: 10.1146/annurev.immunol.26.021607.090326

Serpe, C. J., Kohm, A. P., Huppenbauer, C. B., Sanders, V. M., and Jones, K. J. (1999). Exacerbation of facial motoneuron loss after facial nerve transection in severe combined immunodeficient (scid) mice. J. Neurosci. 19, RC7.

Sharpe, A. H. (2009). Mechanisms of costimulation. Immunol. Rev. 229, 5-11. doi: 10.1111/j.1600-065X.2009.00784.x

Sharpe, A. H., and Freeman, G. J. (2002). The B7-CD28 superfamily. Nat. Rev. Immunol. 2, 116-126. doi: 10.1038/nri727

Simpson, J. E., Ince, P. G., Higham, C. E., Gelsthorpe, C. H., Fernando, M. S., Matthews, F., et al. (2007). Microglial activation in white matter lesions and nonlesional white matter of ageing brains. Neuropathol. Appl. Neurobiol. 33, 670-683. doi: 10.1111/j.1365-2990.2007.00890.x

Steinman, L. (2004). Elaborate interactions between the immune and nervous systems. Nat. Immunol. 5, 575-581. doi: 10.1038/ni1078

Stevenson, P. G., Hawke, S., Sloan, D. J., and Bangham, C. R. (1997). The immunogenicity of intracerebral virus infection depends on anatomical site. J. Virol. 71, 145-151.

Stichel, C. C., and Luebbert, H. (2007). Inflammatory processes in the aging mouse brain: participation of dendritic cells and T-cells. Neurobiol. Aging 28, 1507-1521. doi: 10.1016/j.neurobiolaging.2006.07.022

Streit, W. J., Graeber, M. B., and Kreutzberg, G. W. (1989). Expression of Ia antigen on perivascular and microglial cells after sublethal and lethal motor neuron injury. Exp. Neurol. 105, 115-126. doi: 10.1016/0014-4886(89)90111-8

Stubbe, T., Ebner, F., Richter, D., Engel, O., Klehmet, J., Royl, G., et al. (2012). Regulatory $\mathrm{T}$ cells accumulate and proliferate in the ischemic hemisphere for up to 30 days after MCAO. J. Cereb. Blood Flow Metab. 33, 37-47. doi: $10.1038 /$ jcbfm. 2012.128

Sun, B., and Zhang, Y. (2014). Overview of orchestration of CD4+ T cell subsets in immune responses. Adv. Exp. Med. Biol. 841, 1-13. doi: 10.1007/978-94-0179487-9_1

Sun, H., Huang, Y., Yu, X., Li, Y., Yang, J., Li, R., et al. (2008). Peroxisome proliferator-activated receptor gamma agonist, rosiglitazone, suppresses CD40 expression and attenuates inflammatory responses after lithium pilocarpineinduced status epilepticus in rats. Int. J. Dev. Neurosci. 26, 505-515. doi: 10.1016/j.ijdevneu.2008.01.009

Takatori, H., Kanno, Y., Chen, Z., and O'shea, J. J. (2008). New complexities in helper $\mathrm{T}$ cell fate determination and the implications for autoimmune diseases. Mod. Rheumatol. 18, 533-541. doi: 10.1007/s10165-008-0099-z

Tan, J., Town, T., Crawford, F., Mori, T., Delledonne, A., Crescentini, R., et al. (2002a). Role of CD40 ligand in amyloidosis in transgenic Alzheimer's mice. Nat. Neurosci. 5, 1288-1293. doi: 10.1038/nn968

Tan, J., Town, T., and Mullan, M. (2002b). CD40-CD40L interaction in Alzheimer's disease. Curr. Opin. Pharmacol. 2, 445-451. doi: 10.1016/S1471-4892(02)0 0180-7

Tan, J., Town, T., Paris, D., Placzek, A., Parker, T., Crawford, F., et al. (1999). Activation of microglial cells by the CD40 pathway: relevance to 
multiple sclerosis. J. Neuroimmunol. 97, 77-85. doi: 10.1016/S0165-5728(99)0 0053-3

Togo, T., Akiyama, H., Kondo, H., Ikeda, K., Kato, M., Iseki, E., et al. (2000). Expression of CD40 in the brain of Alzheimer's disease and other neurological diseases. Brain Res. 885, 117-121. doi: 10.1016/S0006-8993(00) 02984-X

Town, T., Tan, J., and Mullan, M. (2001). CD40 signaling and Alzheimer's disease pathogenesis. Neurochem. Int. 39, 371-380. doi: 10.1016/S0197-0186(01)0 0044-4

Tremblay, M. E., Stevens, B., Sierra, A., Wake, H., Bessis, A., and Nimmerjahn, A. (2011). The role of microglia in the healthy brain. J. Neurosci. 31, 16064-16069. doi: 10.1523/JNEUROSCI.4158-11.2011

Vanaja, S. K., Rathinam, V. A., and Fitzgerald, K. A. (2015). Mechanisms of inflammasome activation: recent advances and novel insights. Trends Cell Biol. 25, 308-315. doi: 10.1016/j.tcb.2014.12.009

Vidyadaran, S., Ooi, Y. Y., Subramaiam, H., Badiei, A., Abdullah, M., Ramasamy, R., et al. (2009). Effects of macrophage colony-stimulating factor on microglial responses to lipopolysaccharide and beta amyloid. Cell Immunol. 259, 105-110. doi: 10.1016/j.cellimm.2009. 06.005

Villacampa, N., Almolda, B., Vilella, A., Campbell, I. L., Gonzalez, B., and Castellano, B. (2015). Astrocyte-targeted production of IL-10 induces changes in microglial reactivity and reduces motor neuron death after facial nerve axotomy. Glia 63, 1166-1184. doi: 10.1002/glia. 22807

Vogel, D. Y., Vereyken, E. J., Glim, J. E., Heijnen, P. D., Moeton, M., Van Der Valk, P., et al. (2013). Macrophages in inflammatory multiple sclerosis lesions have an intermediate activation status. J. Neuroinflamm. 10:35. doi: 10.1186/1742-2094-10-35

Waskow, C., Liu, K., Darrasse-Jeze, G., Guermonprez, P., Ginhoux, F., Merad, M., et al. (2008). The receptor tyrosine kinase Flt3 is required for dendritic cell development in peripheral lymphoid tissues. Nat. Immunol. 9, 676-683. doi: 10.1038/ni.1615
Watts, T. H. (2005). TNF/TNFR family members in costimulation of $\mathrm{T}$ cell responses. Annu. Rev. Immunol. 23, 23-68. doi: 10.1146/annurev. immunol.23.021704.115839

Wlodarczyk, A., Lobner, M., Cedile, O., and Owens, T. (2014). Comparison of microglia and infiltrating $\mathrm{CD} 11 \mathrm{c}(+)$ cells as antigen presenting cells for T cell proliferation and cytokine response. J. Neuroinflamm. 11:57. doi: 10.1186/17422094-11-57

Xu, J., and Ling, E. A. (1995). Induction of major histocompatibility complex class II antigen on amoeboid microglial cells in early postnatal rats following intraperitoneal injections of lipopolysaccharide or interferon-gamma. Neurosci. Lett. 189, 97-100. doi: 10.1016/0304-3940(95)11462-6

Yilmaz, G., Arumugam, T. V., Stokes, K. Y., and Granger, D. N. (2006). Role of T lymphocytes and interferon-gamma in ischemic stroke. Circulation 113, 2105-2112. doi: 10.1161/CIRCULATIONAHA.105.593046

Zhu, B., Bando, Y., Xiao, S., Yang, K., Anderson, A. C., Kuchroo, V. K., et al. (2007). CD11b+Ly-6C(hi) suppressive monocytes in experimental autoimmune encephalomyelitis. J. Immunol. 179, 5228-5237. doi: 10.4049/jimmunol.179.8.5228

Zozulya, A. L., Ortler, S., Lee, J., Weidenfeller, C., Sandor, M., Wiendl, H., et al. (2009). Intracerebral dendritic cells critically modulate encephalitogenic versus regulatory immune responses in the CNS. J. Neurosci. 29, 140-152. doi: 10.1523/JNEUROSCI.2199-08.2009

Conflict of Interest Statement: The authors declare that the research was conducted in the absence of any commercial or financial relationships that could be construed as a potential conflict of interest.

Copyright (C) 2015 Almolda, González and Castellano. This is an open-access article distributed under the terms of the Creative Commons Attribution License (CC BY). The use, distribution or reproduction in other forums is permitted, provided the original author(s) or licensor are credited and that the original publication in this journal is cited, in accordance with accepted academic practice. No use, distribution or reproduction is permitted which does not comply with these terms. 